\title{
Notas da História de Roma nas Apologias de São Justino
}

Orientador: Prof. André Luiz Rodrigues da Silva

Pesquisador: Pedro Victor Dacol Piazi

Fonte: Voluntário

\section{Introdução}

Foi realizado um estudo interdisciplinar para a abordagem de um texto cristão antigo como fonte histórica cuja interpretação não se reduz à necessidade de fornecer uma conclusão objetivamente teológica, mas assume o potencial de nos aproximar aos eventos relacionados à Roma Imperial. Partindo da constatação que o processo de transformação do cristianismo tenha passado do contexto de povos semitas para os povos de cultura helênica, ao reconhecer claro sincretismo histórico da religião cristã nascente com a religião pagã, notamos que as informações transmitidas por são Justino Mártir sobre os acontecimentos históricos passam por um processo hermenêutico em diálogo constante com o Império Romano e com o judaísmo da sua época. A abordagem interdisciplinar nos faz verificar quais tenham sido os mecanismos que fizeram com que povos tão diversos entre si, se tornassem tão próximos religiosamente.

\section{Objetivos}

O objetivo da pesquisa é organizar todos os dados históricos que nos façam aproximar da capital do Império Romano no segundo século, da maneira como foram apresentados pela ótica de são Justino. É possível vislumbrar uma série de cidades que são enumeradas como colônias do Império Romano, para entender em que nível de dependência essas se organizavam e como assimilavam a administração centralizada em Roma. Ademais, de tal maneira se reconstrói o cenário romano a partir de algumas localidades, instalações, pontes, casas, 
ritos, serviços públicos e documentação chancelada pela autoridade pública, que isso torna as Apologias irrenunciáveis ao estudo comparativo das fontes históricas da cidade. Selecionaremos as informações sobre cidadãos livres, colonos e escravos, recuperando indícios da vida quotidiana desde a classe mais alta até os mais simples personagens. Encerraremos com as informações sobre como os setores da cidade se comunicavam entre si e como esta rede de comunicação, a seu tempo, contribuiu para a construção dos valores políticos e jurídicos. 